\title{
Green manuring effect of pure and mixed barley - hairy vetch winter cover crops on maize and processing tomato $\mathbf{N}$ nutrition
}

Tosti, Giacomo; Benincasa, Paolo; Farneselli, Michela; Pace, Roberta; Tei, Francesco;

Guiducci, Marcello; Thorup-Kristensen, Kristian

Published in:

European Journal of Agronomy

DOI:

10.1016/j.eja.2012.06.004

Publication date:

2012

Document version

Early version, also known as pre-print

Citation for published version (APA):

Tosti, G., Benincasa, P., Farneselli, M., Pace, R., Tei, F., Guiducci, M., \& Thorup-Kristensen, K. (2012). Green manuring effect of pure and mixed barley - hairy vetch winter cover crops on maize and processing tomato $\mathrm{N}$ nutrition. European Journal of Agronomy, 43, 136-146. https://doi.org/10.1016/j.eja.2012.06.004 


\title{
Green manuring effect of pure and mixed barley - hairy vetch winter cover crops on maize and processing tomato $\mathrm{N}$ nutrition
}

\author{
Giacomo Tostia ${ }^{\mathrm{a}, *}$, Paolo Benincasa $^{\mathrm{a}}$, Michela Farneselli ${ }^{\mathrm{a}}$, Roberta Pace ${ }^{\mathrm{a}}$, Francesco Tei ${ }^{\mathrm{a}}$, \\ Marcello Guiducci ${ }^{\mathrm{a}}$, Kristian Thorup-Kristensen ${ }^{\mathrm{b}}$ \\ a University of Perugia, Department of Agricultural and Environmental Sciences, Borgo XX Giugno, 74, 06121 Perugia, Italy \\ ${ }^{\mathrm{b}}$ University of Copenhagen, Faculty of Life Sciences, Department of Agriculture and Ecology, 2630 Taastrup, Denmark
}

\section{A R T I C L E I N F O}

\section{Article history:}

Received 21 February 2012

Received in revised form 8 June 2012

Accepted 11 June 2012

\section{Keywords:}

Organic farming

Legumes

Sowing proportions

Mediterranean environment

Critical N

Green manuring

\begin{abstract}
A B S T R A C T
Adopting mixtures between legumes and non legumes can be an efficient tool to merge the advantages of the single species in the fall-sown cover crop practice. Nevertheless there is a lack of information on how the species proportion may affect $\mathrm{N}$ accumulation and $\mathrm{C} / \mathrm{N}$ of the cover crops and how this can influence the $\mathrm{N}$ uptake and $\mathrm{N}$ status of different subsequent summer cash crops.

In this study the N effect of barley (Hordeum vulgare L.) and hairy vetch (Vicia villosa Roth.) grown in pure stands or in mixtures with different sowing proportion was tested on maize (Zea Mays L.) and processing tomato (Lycopersicon esculentum Mill.). Cover crop $\mathrm{N}$ accumulation and $\mathrm{C} / \mathrm{N}$ ratio were monitored during the whole growing cycle, and $\mathrm{CO}_{2}$ flux from the soil was measured after their incorporation into the soil. $\mathrm{N}$ status of the following cash crops was evaluated by comparing the observed data with the appropriate critical N dilution curves.

The results highlight the effectiveness of mixtures for the management of the winter cover crop practice. In the two considered years, the species proportion influences the aboveground biomass (ranging from 2.90 to $5.94 \mathrm{Mg} \mathrm{ha}^{-1}$ ) and $\mathrm{N}$ accumulation (ranging from 73.8 to $183.2 \mathrm{~kg} \mathrm{ha}^{-1}$ ) of the mixtures. The legume component, even at low proportion, increased the $\mathrm{N}$ accumulation of the cover crop of $148 \%$ (in 2006) and 134\% (in 2007) compared to pure stand barley. Also the biomass quality of the cover crops was greatly affected by species proportion (e.g. $\mathrm{C} / \mathrm{N}$ ranging from 12.0 to 18.9 ) and this aspect showed a clear effect on the $\mathrm{N}$ availability for the subsequent crop. $\mathrm{N}$ effect $\left(N_{\text {eff }}\right)$ of the different cover crop mixtures (especially those with high barley proportions) brought tomato much closer to the critical $\mathrm{N}$ value than they did with maize. The basis of the relationship between cover crop C/N and $N_{\text {eff }}$ was confirmed, so mixtures can be used to adjust the extent and timing of mineralisation of the incorporated biomass to the subsequent cash crop requirements. Prediction of the cash crops $\mathrm{N}$ status on the cover crop $\mathrm{C} / \mathrm{N}$ appears to be a useful approach, but, it may be important to take the characteristics of the following cash crop into account.
\end{abstract}

(C) 2012 Elsevier B.V. All rights reserved.

\section{Introduction}

Nitrogen $(\mathrm{N})$ management in low-input and organic farming systems relies mainly on preventive measures, such as the introduction of legumes in crop rotations (van Kessel and Hartley, 2000), the use of winter cover crops and the adoption of conservative soil tillage techniques (Lampkin, 1990; Stockdale et al., 2002; ThorupKristensen et al., 2003). Recently, there has been an increased interest in cover crops also in conventional agriculture, mainly due to a rise in the price of fertilisers and to the increased awareness of

\footnotetext{
* Corresponding author. Tel.: +39 075585 6333; fax: +39 0755856344 .

E-mail addresses: giacomo.tosti@gmail.com, tostella2@alice.it (G. Tosti).
}

environmental issues (Salmeron et al., 2011; Gabriel and Quemada, 2011).

In the Mediterranean environment, winter cover crops are mainly grown because of their capacity to incorporate $\mathrm{N}$ during the winter season and hand it over to the succeeding cash crop in spring-summer, upon the incorporation of aboveground biomass residues into the soil (Teasdale et al., 2008; Kramberger et al., 2009). Such 'nitrogen effect' results from two combined processes: on one side the uptake of $\mathrm{N}\left(N_{\text {upt }}\right)$ by the cover crop during its growing cycle and, on the other side, the release of $\mathrm{N}$ by mineralisation after the incorporation of aboveground biomass residues into the soil (Thorup-Kristensen, 1994a; Thorup-Kristensen and Nielsen, 1998). Therefore, the large $N_{\text {upt }}$ variability of the subsequent cash crops, that mainly depends on crop potential and soil $\mathrm{N}$ availability (Vos and Van der Putten, 1997; Benincasa et al., 2010), and the 
occurrence of asynchrony between $\mathrm{N}$ release from the residues and the subsequent cash crop, still need a comprehensive interpretation in the light of the "N effect" approach. All those aspects interfere, in fact, with the reliability of the cover crops as efficient tool for the agroecosystem $\mathrm{N}$ management. Asynchrony could occur as "excess-asynchrony" when release occurs at a time when plant demand is restricted or non-existent; or as "insufficientasynchrony" when nutrient supply from the mineralisation of the biomass is too slow to meet plant needs (Myers et al., 1994).

One key aspect relates to the selection of species. When cover crops are specifically used for green manuring purposes, this selection depends on the primary aims to be achieved. Indeed, legumes are mainly used for their ability to fix, accumulate and supply large amounts of N (Ledgard and Giller, 1995; Peoples et al., 1995; Cazzato et al., 2003; Caporali et al., 2004; Campiglia et al., 2010), while non-legumes are mainly used to prevent soil erosion, trap $\mathrm{N}$ and reduce its leaching to the water table (Vos and Van der Putten, 2001; Macdonald et al., 2005; Constantin et al., 2011).

Adopting mixtures between legumes and non legumes can be an efficient tool to merge the advantages of the single species in the cover crop practice (Ranells and Wagger, 1997) achieving both environmental and agronomic benefits (Crews and Peoples, 2005). The use of mixtures leads to a radical modification of the biochemical composition of the aboveground biomass that will be incorporated into the soil (Tosti et al., 2010), hence it could represent an important factor affecting the $\mathrm{N}$ mineralisation and the $\mathrm{N}$ availability for the subsequent crop. Moreover, the intercropping of legumes and non legumes frequently leads to facilitative interactions (Ofori and Stern, 1987; Jensen, 1996; Hauggaard-Nielsen and Jensen, 2005; Fan et al., 2006), but this advantage has never been evaluated considering how the proportion between the species affects the $\mathrm{N}$ effect for different summer cash crops.

The objectives of this study were to: (i) analyse the dynamics of growth (with particular reference to total $\mathrm{N}$ content and $\mathrm{C} / \mathrm{N}$ ratio) for two cover crop species (hairy vetch, Vicia villosa Roth., and barley, Hordeum vulgare L.) cultivated in pure stands and in mixtures characterised by varying proportions among the different species; (ii) examine how the mixture composition affects the nitrogen effect for the succeeding crop, and (iii) evaluate possible differences between two summer crops (maize, Zea Mays L., and processing tomato, Lycopersicon esculentum Mill.) in terms of response to the amount of $\mathrm{N}$ supplied by the cover crops in pure stands or mixtures.

\section{Materials and methods}

\subsection{Experimental site and design}

Field experiments were carried out in two growing seasons (2005-2006 and 2006-2007) at the Experimental Station of the Department of Agricultural and Environmental Sciences of the University of Perugia (Papiano, Central Italy, $43^{\circ} \mathrm{N}, 165 \mathrm{~m}$ a.s.l.). The soil was a clay-loam (Fluventic Haplustept) with the $0-0.5 \mathrm{~m}$ soil layer containing $46 \%$ silt, $33 \%$ clay, $20 \%$ sand and $1.2 \%$ organic matter. The $\mathrm{pH}_{\mathrm{H}_{2} \mathrm{O}}$ was 7.8; the content of extractable Olesen-P was $29.5 \mathrm{mg} \mathrm{kg}^{-1}$, and exchangeable $\mathrm{K}$ was $254 \mathrm{mg} \mathrm{kg}^{-1}$.

Complete weather data (including temperature and rainfall) were obtained from an automatic meteorological station inside the experimental site. In both years, the preceding crop was sunflower. After harvesting operation the residues of sunflower were cut and incorporated into the soil by a superficial $(0.25 \mathrm{~m})$ ploughing followed by harrowing. The seed bed preparation was optimal in both years. The experiment consisted of two consecutive phases, the first being the cultivation of autumn-winter cover crops until the killing date, the second being the cultivation of two spring-summer cash crops.

As cover crops, two species were used, i.e. barley (H. vulgare L., cultivar Amillis) and hairy vetch ( $V$. villosa Roth., cultivar Capello). These species were sown as pure crops at the ordinary sowing rates (400 seeds of barley $\mathrm{m}^{-2}, \mathrm{~B} 100 ; 200$ seeds of vetch $\mathrm{m}^{-2}, \mathrm{V100}$ ) and as mixtures, with varying seed ratios according to the replacement principle (de Wit and van den Bergh, 1965; Connolly, 1986). In detail, the following three combinations were chosen: barley at $75 \%$ of its full sowing rate + vetch at $25 \%$ of its full sowing rate $\left(300+50\right.$ seeds $\mathrm{m}^{-2}$; B75V25), barley $50 \%+$ vetch $50 \%(200+100$ seeds $\mathrm{m}^{-2}$; B50V50) and barley $25 \%+$ vetch $75 \%(100+150$ seeds $\mathrm{m}^{-2}$; B25V75). Beside the cover crops, two control plots were also added to the experiment (see later), wherein pure barley was grown as in B100, but the aboveground biomass was removed instead of being incorporated into the soil at the killing date. The experimental design was a completely randomized block with 8 replicates in 2005-2006 and 6 replicates in 2006-2007. The plot size was $80 \mathrm{~m}^{2}$ in both years.

After the killing of cover crops, grain maize ( $Z$. mays L., cultivar Arzano FAO class 400) and processing tomato (L. esculentum Mill., cultivar PS1296) were sown/planted in 4 (2006) or 3 (2007) blocks each. Considering the aforementioned control plots (two for each block), these were used to accommodate respectively an unfertilised control (N0) and a fertilised control (N200). In such way, the pre-emptive competition effect (Thorup-Kristensen, 1993) occurred also in the N0 and N200 control treatments. N200 received $200 \mathrm{~kg} \mathrm{Nha}^{-1}$ as urea at sowing (in maize), or via fertigation (in processing tomato), while no other plots receive any mineral fertilisation input.

\subsection{Crop management}

Cover crops were sown on 28.10.2005 and 27.10.2006 in rows spaced $0.15 \mathrm{~m}$ apart. Barley and hairy vetch in the mixtures were sown in the same row. No $\mathrm{N}$ fertilisation was supplied to the cover crops while Phosphorus and Potassium were applied to all plots at a rate of $75 \mathrm{~kg} \mathrm{ha}^{-1}$ of $\mathrm{P}_{2} \mathrm{O}_{5}$ and $\mathrm{K}_{2} \mathrm{O}$, respectively, each at cover crop planting. No diseases or weed control was performed.

At killing dates (12.04.2006 and 03.04.2007) the hairy vetch plants were at beginning of flowering and barley plants at ear emergence. Cover crop aboveground biomass was mowed, finely chopped and immediately incorporated into the soil ( $0.2 \mathrm{~m}$ depth) by a rotary cultivator equipped with scissor organs and a backroller.

Maize was sown with a pneumatic drill on 24.04.2006 and on 19.04.2007 and the emergence occurred on 08.05.2006 and 03.05.2007; two weeks later plant density was adjusted by thinning out to 8 plants $\mathrm{m}^{-2}$. Processing tomato was bedded using a drawn row crop transplanter on 15.05.2006 and 15.05.2007 in twin-rows $(1.2 \mathrm{~m}+0.4 \mathrm{~m})$ at 3.3 plants $\mathrm{m}^{-2}$. Both cash crops were drip-irrigated twice a week for all treatments, according to ETc (Allen et al., 1998). Pest control was never necessary during the growing cycle, while weeds were thoroughly controlled by hand. Copper was applied during the processing tomato crop season in order to control foliar diseases.

\subsection{Plant sampling and analytical determinations}

Aboveground biomass accumulation of the cover crops was determined by periodical samplings of plants from a surface area of $1.2 \mathrm{~m}^{2}$ per each plot. Plant sampling was performed at 75,103 , 138, 159, 166 Days After Sowing (DAS) in 2005-2006, and at 47, $81,124,139,158$ DAS in 2006-2007. At each sampling date, the aboveground biomass of vetch and barley in mixtures was separated by hand. The harvested aboveground biomass was weighed, 
oven dried at $80^{\circ} \mathrm{C}$, ground to a fine powder and stored for the analysis of $\mathrm{N}$ content (see later).

In order to assess the mineralisation rhythm, $\mathrm{CO}_{2}$ flux from soil $\left(\mu \mathrm{mol} \mathrm{m}{ }^{-2} \mathrm{~s}^{-1}\right.$ ) was monitored after the incorporation of cover crops (Kuzyakov, 2006; Bardgett and Wardle, 2010), by using an ADC-LCA4 gas analyser (Analytical Development Company Ltd, UK), equipped with a soil respiration hood device. Owing to the time required for these determinations, a total of 7 and 6 measurements were taken respectively in the two years, on B100, V100, B50V50 and N0. Measurements were taken in 4 sites per each plot between 10:00 a.m. and 12:00 a.m. with the purpose of avoiding extreme heat fluxes. In order to obtain a reliable estimate of the mineralisation of the cover crop residues, the amount of $\mathrm{CO}_{2}$ evolved from NO was subtracted from the measurements taken on all the other plots $\left(\Delta \mathrm{CO}_{2}\right)$.

The aboveground biomass accumulation of maize was determined by sampling 6 plants per plot, at 23, 29, 43, 57, 71, 80 and 151 Days After Emergence (DAE) in 2006 and at 21, 35, 47, 63, 77 and 151 DAE in 2007. Maize grain yield was determined at the end of the growing season by harvesting 30 maize plants from the central area of each plot, and weighing the whole above ground mass and separately, the yield of grain. The aboveground biomass accumulation of processing tomato was determined by sampling 4 plants per plot (18 plants at final harvest) at approx. 2-week intervals, starting from 15 Days After Transplant (DAT) in 2006 and 17 DAT in 2007 until the final harvest (106 DAT in 2006 and 104 DAT in 2007) for a total of 7 sampling dates. In both years, the fruit yield of processing tomato was determined at final harvest: in the core area of each plot, 20 tomato plants were harvested manually and the fruits were separated from the stem and leaf, and then they were divided into marketable (red and orange fruits) and unmarketable fruits (green and rotten fruits) and weighed.

As already mentioned for cover crops, the harvested aboveground biomass was weighed, oven dried at $80^{\circ} \mathrm{C}$ and ground to a fine powder. For both cover crops and cash crops, an automatic analyser (FlowSys, Systea, Italy) was used to measure reduced-N concentrations in Kjeldhal digests prepared following the method proposed by Isaac and Johnson (1976). The $\mathrm{C} / \mathrm{N}$ ratio of the cover crops was estimated assuming that the $C$ content of the aboveground biomass was equal to $42 \%$ of the dry matter (ThorupKristensen, 1994b; Quemada, 2004).

\subsection{Data analysis}

$\mathrm{N}$ status (i.e. limiting/optimal/luxury $\mathrm{N}$ consumption) was evaluated over the whole cycle of both cash crops, by comparing the actual $\mathrm{N}$ concentration in plant tissues with the critical $\mathrm{N}$ concentration curves, as determined in previous studies in maize (Plénet and Lemaire, 2000) and processing tomato (Tei et al., 2002).

$\mathrm{N}$ effect $\left(N_{\text {eff }}\right)$ of cover crops on the following cash crops was estimated as follows:

$N_{\text {eff }, i}=N_{\text {uptCC, } i}-N_{\text {uptNo }}$

where $i$ represents the different cover crop treatments (from 1 to 5 levels), $N_{\text {uptcc }}$ represents the $N_{\text {upt }}\left(\mathrm{kg} \mathrm{Nha}^{-1}\right)$ at harvest in each cash crop following each cover crop treatment and $N_{\text {uptNo }}$ represents the $N_{\text {upt }}$ recorded in NO. As above mentioned, the pre-emptive competition occurred also in N0, so $N_{\text {eff }}$ only considers the mineralisation effect of the cover crop Therefore, $N_{\text {eff }}$ can be compared across years, cover crops and cash crops.

For a better discussion of results, $N_{\text {eff }}$ values obtained with Eq. (1) were compared with those predicted from the characteristics of the incorporated aboveground biomass for each cover crop by using the model proposed by Thorup-Kristensen (1994b):

$N_{\text {eff }}=0.75 N-0.03 C$ where $\mathrm{N}$ and $\mathrm{C}$ represent the total nitrogen and carbon content in the cover crop aboveground biomass.

For each experimental treatment and recorded variable, means and standard errors were calculated and reported on the tables/graphs. The observed data at the final sampling date of the cover crops (aboveground biomass dry weight, $\mathrm{N}$ accumulation and $\mathrm{C} / \mathrm{N}$ ratio) and at cash crop harvest (aboveground biomass dry weight, $\mathrm{N}$ uptake, commercial yield) were subjected to the analysis of variance (ANOVA), by entering the year and experimental treatment (N0, N200 and cover crops) as fixed effects. Statistical analyses were performed by using the software $R$ (R Development Core Team, 2009).

\section{Results}

\subsection{Weather conditions}

The total amount of rain during the first experimental year $(728 \mathrm{~mm})$ was substantially higher than during the second $(476 \mathrm{~mm})$, while the two years were quite similar in terms of daily mean air temperature (Fig. 1). Likewise, the difference between precipitations and Penman-Monteith evapotranspiration $(\Delta, \mathrm{mm})$ was very high during the first year and rather low during the second. The main difference in terms of rain frequency and amount between the two years was observed at a very early stage of the cover crop cycle (i.e. in November, December and early January; Fig. 1), while the rest of the season was rather similar in the two years, except for a short period of intense precipitations at the end of September 2006. The time interval from cover crop incorporation into the soil to cash crop establishment was characterised by higher $\Delta$ in 2006 as compared to 2007 (Fig. 1).

\section{2. $N$ accumulation dynamics and aboveground biomass accumulation of cover crops}

A uniform plant emergence was observed in both years, about two weeks after sowing. As expected, $N_{\text {acc }}$ dynamics in barley was very different as compared to vetch (Fig. 2 ). In both years, $N_{\text {acc }}$ rate of barley was fast during the initial phase, but slowed down later on. Considering the amount of $N_{\text {acc }}$ in 2006, barley showed low values during the whole growing cycle and the differences among the four sowing proportions were negligible; on the other hand, in 2007, total $N_{\text {acc }}$ of these species was consistently higher than in 2006 and, during the first part of the growing cycle, it was positively affected by increasing sowing proportions; however, no significant differences among treatments were observed at the last sampling date (Fig. 2). $N_{\text {acc }}$ dynamics observed in hairy vetch showed a slow initial phase followed by an increasing rate until the incorporation of this crop into the soil; in both years, the amount of $N_{\text {acc }}$ increased with increasing vetch sowing proportions, in a statistically significant manner, starting from the 3rd sampling date onwards (Fig. 2).

The last sampling dates (soil incorporation of cover crops) are particularly relevant in terms of plant nutrition for the following cash crops. With this respect, no significant 'treatment by year' interactions were observed, showing that effects were consistent across years.

Considering the final accumulated aboveground biomass (Table 1), barley showed lower values in 2005-2006 with respect to 2006-2007. Otherwise, vetch was not affected by the year. Mixtures showed a high and stable aboveground biomass accumulation in 2007, while in 2006 values increased with the proportion of vetch. Besides, in both years total aboveground biomass accumulation of mixtures was higher compared to that of pure barley (Table 1).

Total $N_{\text {acc }}$ by the cover crops in the whole aboveground biomass (barley + vetch), was significantly $(P=0.0015)$ higher in 2007 with 


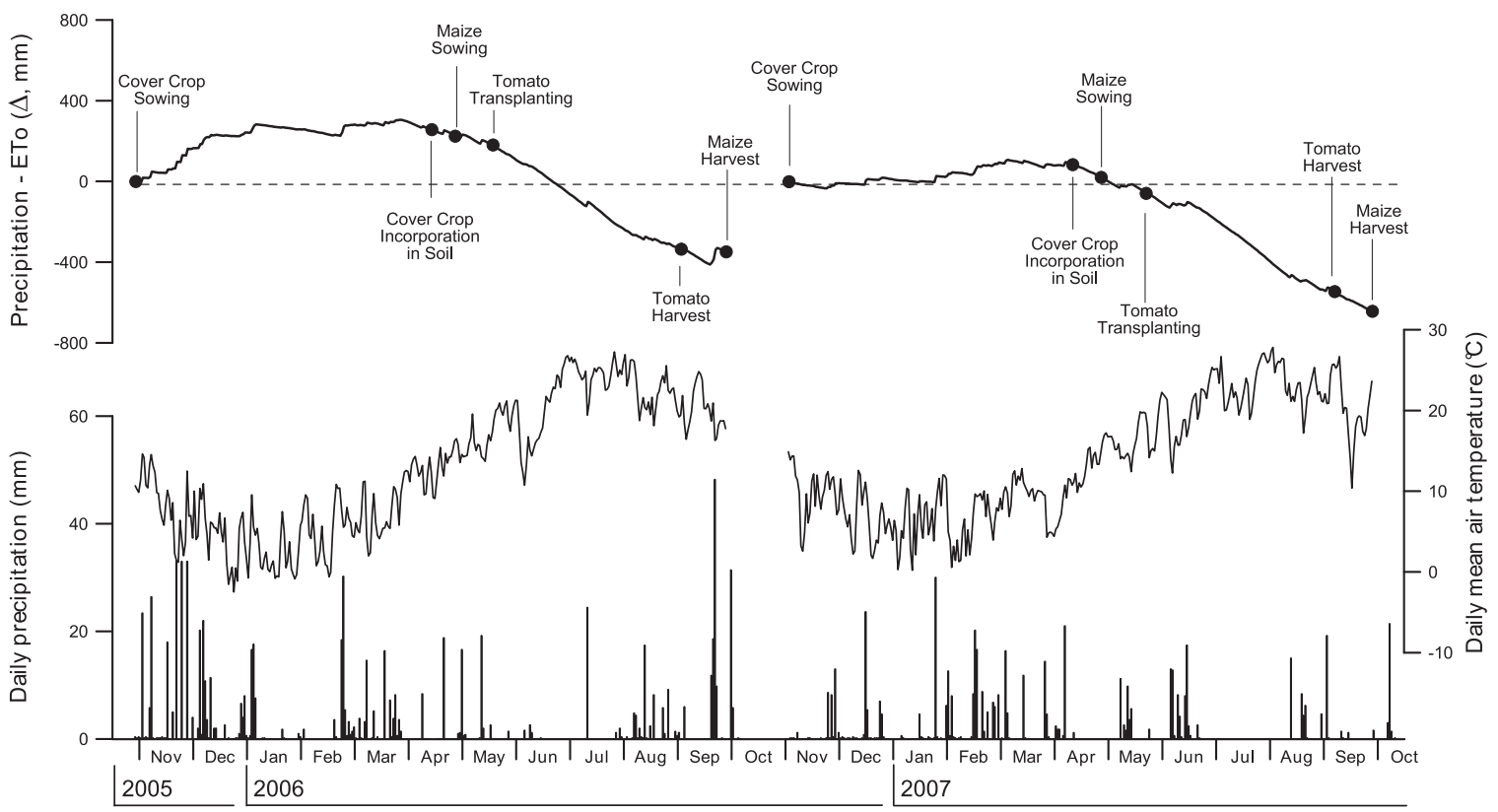

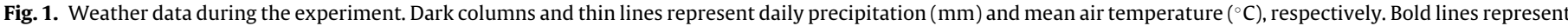
the difference between cumulated rainfall and cumulated Penman-Monteith evapotranspiration ( $\Delta$, mm). The timing of the main field operations is also reported.

respect to 2006 ( 137.1 vs. $104.2 \mathrm{~kg} \mathrm{~N} \mathrm{ha}^{-1}$ on average). As expected, $N_{\text {acc }}$ was high in pure vetch $\left(187.0 \mathrm{~kg} \mathrm{Nha}^{-1}\right.$ as an average of the two years) and low in pure barley $\left(39.7 \mathrm{~kg} \mathrm{Nha}^{-1}\right)$, while $N_{\text {acc }}$ of mixtures increased with the proportion of vetch within the above range and the observed differences were always significant $(P<0.001)$. Regarding each single species, $N_{\text {acc }}$ of barley was not affected by the sowing proportion, but only by the year $\left(P=2.433 \mathrm{e}^{-10} ; 25.6\right.$ vs. $51.2 \mathrm{~kg} \mathrm{Nha}^{-1}$ respectively in 2006 and 2007). On the other hand, $N_{\text {acc }}$ of vetch was not significantly affected by the year and it was significantly affected by sowing proportion $\left(P=5.761 \mathrm{e}^{-8}\right)$, ranging on average from 54.6 to $187.0 \mathrm{~kg} \mathrm{Nha}^{-1}$.
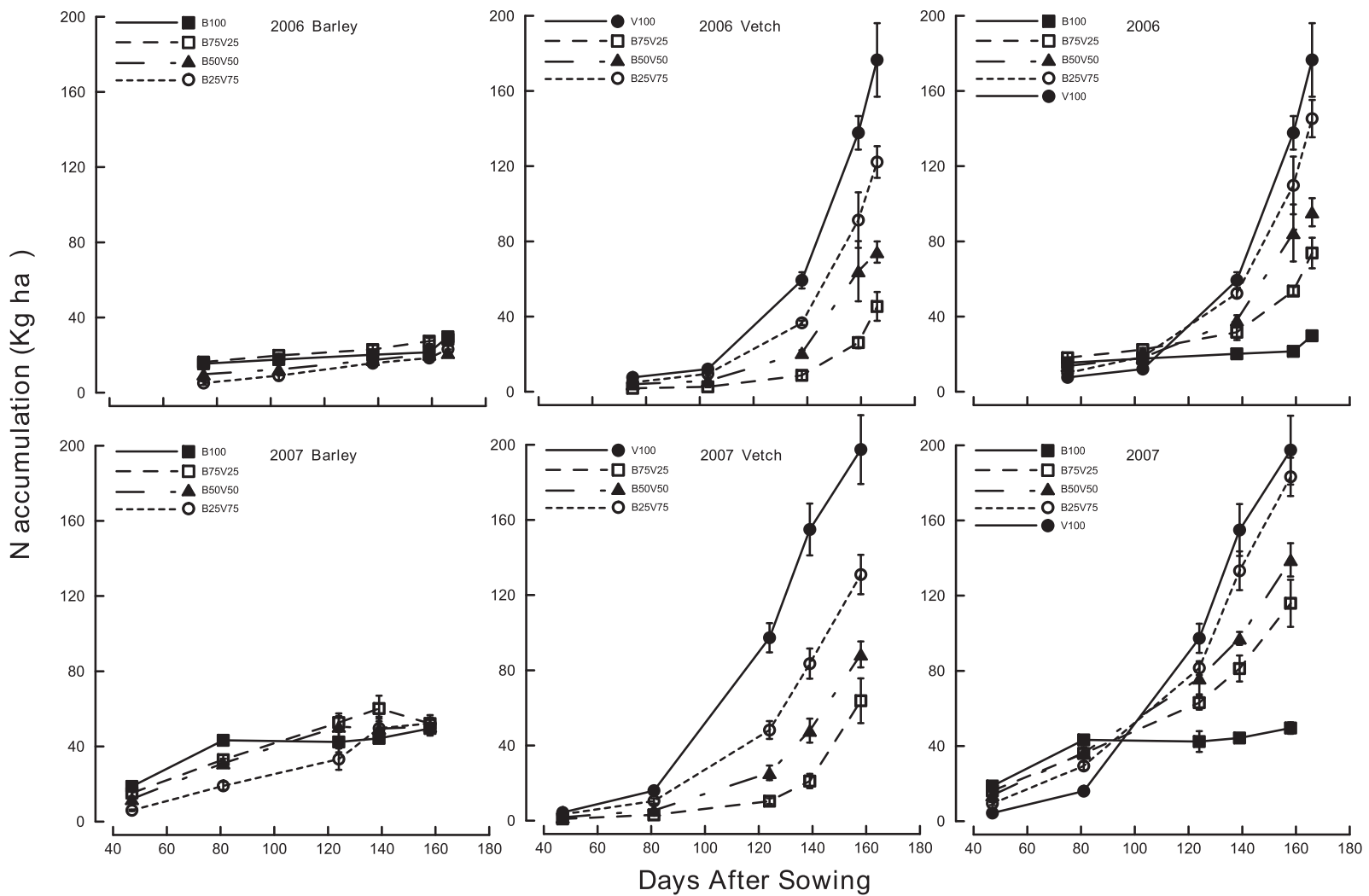

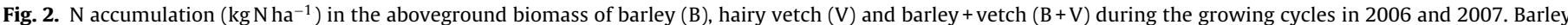

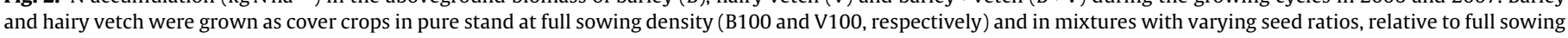
density, i.e. $75 \%$ barley $+25 \%$ vetch (B75V25), 50\% + 50\% (B50V50) and 25\%+75\% (B25V75). Bars indicate \pm 1 standard error. 
Table 1

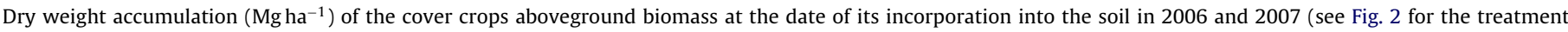
abbreviations). Standard errors (in brackets) and results of the analysis of variance are also reported.

\begin{tabular}{|c|c|c|c|c|}
\hline & & \multicolumn{3}{|c|}{ Aboveground biomass ( $\left.\mathrm{Mg} \mathrm{ha}^{-1}\right)$} \\
\hline & & Barley & Vetch & Total \\
\hline \multirow[t]{5}{*}{2006} & B100 & $2.34(0.161)$ & - & $2.34(0.161)$ \\
\hline & B75V25 & $1.70(0.155)$ & $1.20(0.189)$ & $2.90(0.123)$ \\
\hline & B50V50 & $1.16(0.081)$ & $2.26(0.063)$ & $3.43(0.050)$ \\
\hline & B25V75 & $1.00(0.065)$ & $3.13(0.174)$ & $4.12(0.193)$ \\
\hline & V100 & - & $4.51(0.262)$ & $4.51(0.262)$ \\
\hline \multirow[t]{8}{*}{2007} & B100 & $4.17(0.154)$ & - & $4.17(0.154)$ \\
\hline & B75V25 & $3.67(0.150)$ & $1.36(0.158)$ & $5.03(0.082)$ \\
\hline & B50V50 & $2.94(0.185)$ & $2.08(0.099)$ & $5.02(0.182)$ \\
\hline & B25V75 & $2.82(0.185)$ & $3.12(0.191)$ & $5.94(0.239)$ \\
\hline & V100 & - & $4.82(0.224)$ & $4.82(0.224)$ \\
\hline & Treatment $(\mathrm{T})$ & $* * *$ & $* * *$ & $* * *$ \\
\hline & $\operatorname{Year}(\mathrm{Y})$ & $* * *$ & ns & $* * *$ \\
\hline & T x Y & ns & ns & ns \\
\hline
\end{tabular}

***: Significantly different at $P<0.001$

**: Significantly different at $P<0.01$

*: Significantly different at $P<0.05$

ns: not significant

$\mathrm{N}$ concentration on dry aboveground biomass (N\%) recorded at the final sampling date was not affected by sowing proportion in hairy vetch $(3.72 \pm 0.148 \%$ in 2006 and $4.02 \pm 0.131 \%$ in 2007$)$; while it increased linearly $\left(R^{2}=0.893, n=8\right)$ in barley following the increase of vetch proportion on the total aboveground biomass (Fig. 3).

\subsection{C/N ratio of cover crops}

$\mathrm{C} / \mathrm{N}$ ratio was affected by the sowing proportion in barley and it increased during the growing cycle. Otherwise, this same ratio in vetch was stable around 10 and unaffected by sowing proportions in 2006, though in 2007 it decreased from 15 to 20 during early growth to 10 at later stages. In both years, $\mathrm{C} / \mathrm{N}$ in mixtures ranged from 10 to 20 and it was reduced as the sowing proportion of vetch was increased. $\mathrm{C} / \mathrm{N}$ remained relatively stable over time, especially when compared to the pure stand barley (Fig. 4).

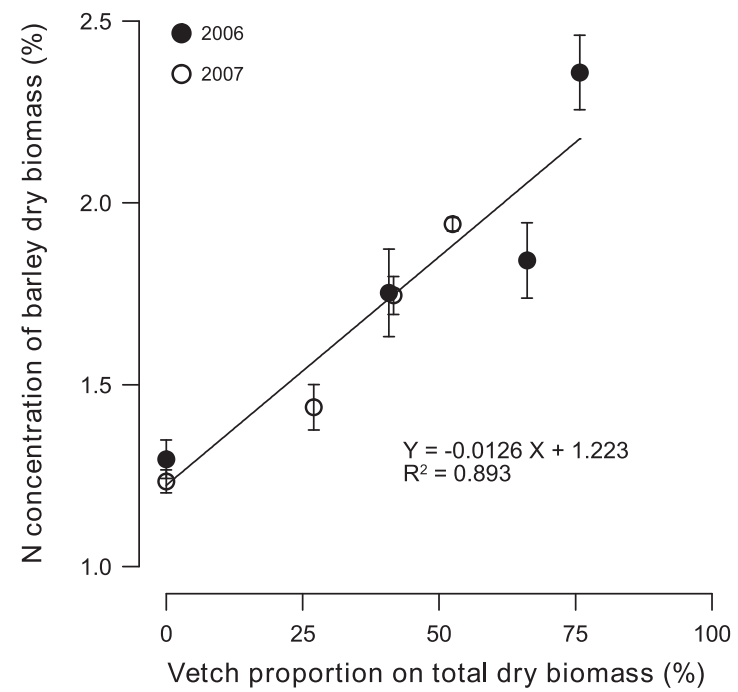

Fig. 3. N concentration in dry aboveground biomass (\%) of barley, as affected by the vetch proportion on total aboveground biomass at the date of cover crop incorporation into the soil. Symbols represent observed data (2006: closed circle; 2007: open circle). The bold line represents the linear regression fitted into both years of data. Vertical bars indicate \pm 1 standard error.
Considering in more detail the last sampling date (cover crop incorporation), no significant 'treatment by year' interactions were observed and $\mathrm{C} / \mathrm{N}$ ratios for whole aboveground biomass were not affected by the year $(P=0.3765)$, but tended to decrease significantly $\left(P=2.009 \mathrm{e}^{-12}\right)$ as the proportion of vetch in the mixtures increased, ranging from 34.1 (pure barley) to 10.8 (pure vetch) on average. Considering separately the two components of the mixture, $\mathrm{C} / \mathrm{N}$ ratios of barley were significantly affected $\left(P=1.313 \mathrm{e}^{-4}\right)$ only by sowing proportions and ranged from 34.0 (pure barley) to 20.5 (B25V75). Otherwise, $\mathrm{C} / \mathrm{N}$ ratios of vetch were significantly affected only by the year $(P=0.0167)$ and they were higher in 2006 (11.6) than in 2007 (9.8).

\section{4. $\mathrm{CO}_{2}$ flux from the soil}

On average, $\mathrm{CO}_{2}$ flux rates were higher in pure and mixed vetch than in pure barley. The general trend of $\mathrm{CO}_{2}$ flux dynamics was quite similar in the two years, including an initial peak at 9 Days After the Incorporation (DAI) into the soil in 2006 and at 15 DAI in 2007, followed by a sudden fall, which was particularly sharp in V100 and B50V50 and less evident in B100 (Fig. 5). As compared to 2006 , in 2007 the above fall was more evident. In both years, the $\mathrm{CO}_{2}$ flux from the soil returned to the same values as base values (NO) approximately from $50 \mathrm{DAI}$. Afterwards, the $\Delta \mathrm{CO}_{2}$ stayed close to 0 , except in 2007, when the $\mathrm{CO}_{2}$ efflux recorded in $\mathrm{V} 100$, rather than showing a low asymptotic behaviour, decreased to values lower than in the control (NO), implying negative $\Delta \mathrm{CO}_{2}$ values. During the first $40 \mathrm{DAI}$ of both years, the estimated proportion of $C$ released from the soil on the total C incorporated ranged from 35\% to 65\%, and the release from the intercrop was higher than from either pure barley or vetch (Fig. 5).

\section{5. $N$ status, $N$ effect and yield of the cash crops}

At a very early stage, maize N nutritional status after V100 was close to optimal, but became sub-optimal when maize reached a dry aboveground biomass of approximately $5 \mathrm{Mgha}^{-1}$. Indeed, even the pure legume did not have sufficient effect on maize $\mathrm{N}$ nutritional status, particularly in 2007. Even though $\mathrm{N}$ deficiency was moderate, it was constant and lasted until the end of the maize growing cycle. Pure barley had the smallest effect on maize, and the concentration of $\mathrm{N}(\%)$ within this cash crop was even below the 

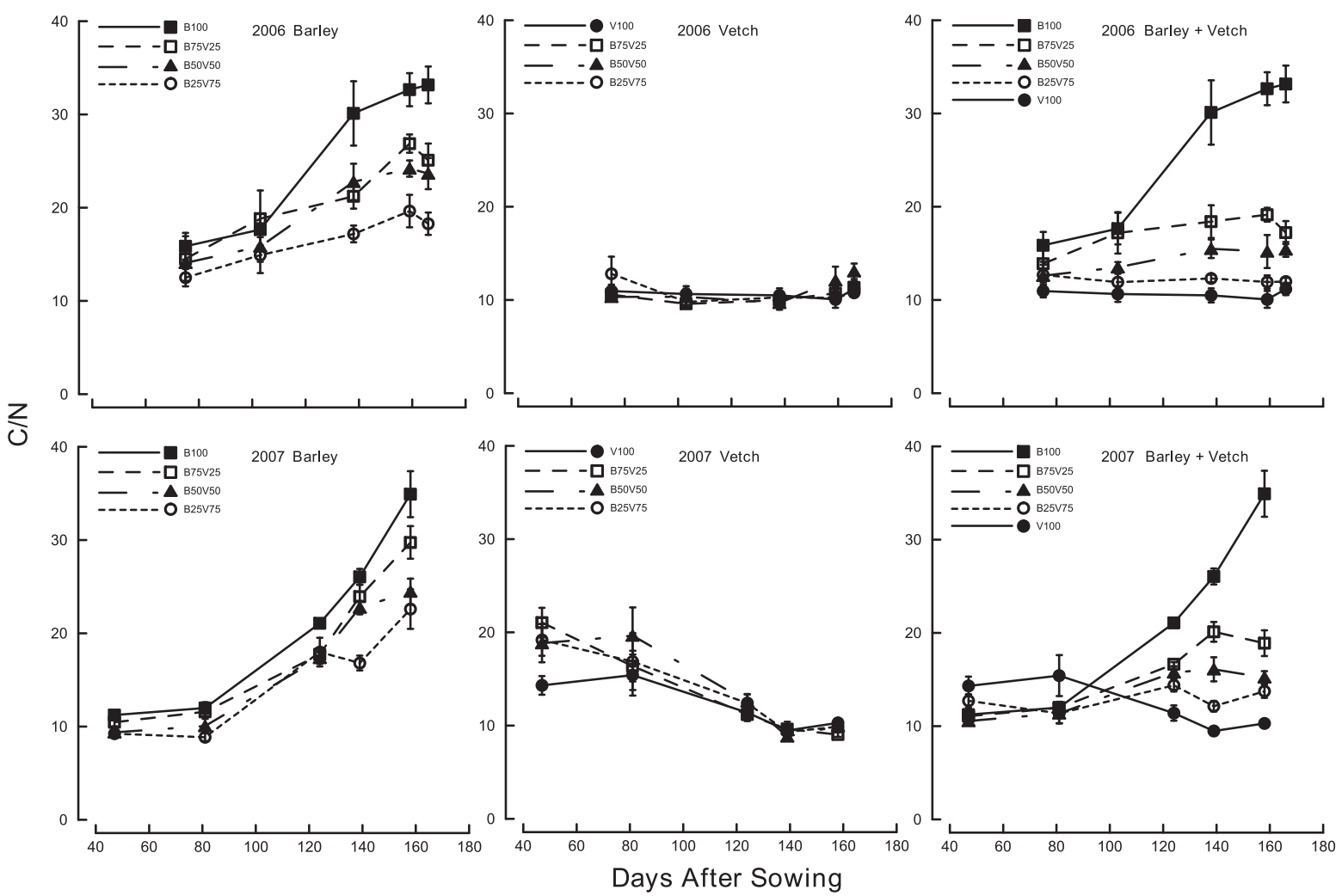

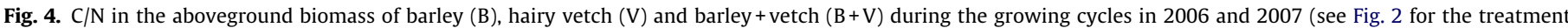
abbreviations). Bars indicate \pm 1 standard error.

level observed in N0. All the mixtures, particularly B75V25, showed a scarce effect on the maize $\mathrm{N}$ status (Fig. 6).

Processing tomato responded more positively to the cover crops in terms of $\mathrm{N}$ status (Fig. 6). When grown after V100, processing tomato could find optimal $\mathrm{N}$ conditions during the whole crop cycle and it was rarely found to be significantly above the critical $\mathrm{N}$ dilution curve. Thus, V100 was found to be a more suitable fertilisation strategy than $\mathrm{N} 200$, which produced a continuous luxury $\mathrm{N}$ consumption. Otherwise, pure barley resulted in an inadequate $\mathrm{N}$ status of processing tomato, similar to NO. The mixtures between barley and vetch gave a different effect on $\mathrm{N}$ nutritional status of tomato and, while this cash crop was close to the critical curve when grown after B25V75, it was in sub-optimal conditions after B75V25. After B50V50 the N status of tomato was intermediate (Fig. 6).

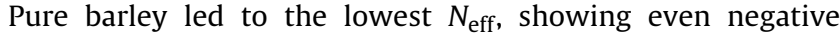
values in 2007, while pure vetch showed the highest $N_{\text {eff }}$, especially in 2007. Mixtures showed intermediate $N_{\text {eff }}$ in both cash crops, in close agreement with the proportion of vetch within the aboveground biomass of cover crops (Fig. 7). Nevertheless, when processing tomato was grown after the mixtures, it showed $N_{\text {eff }}$ values consistently higher than maize. Furthermore, these
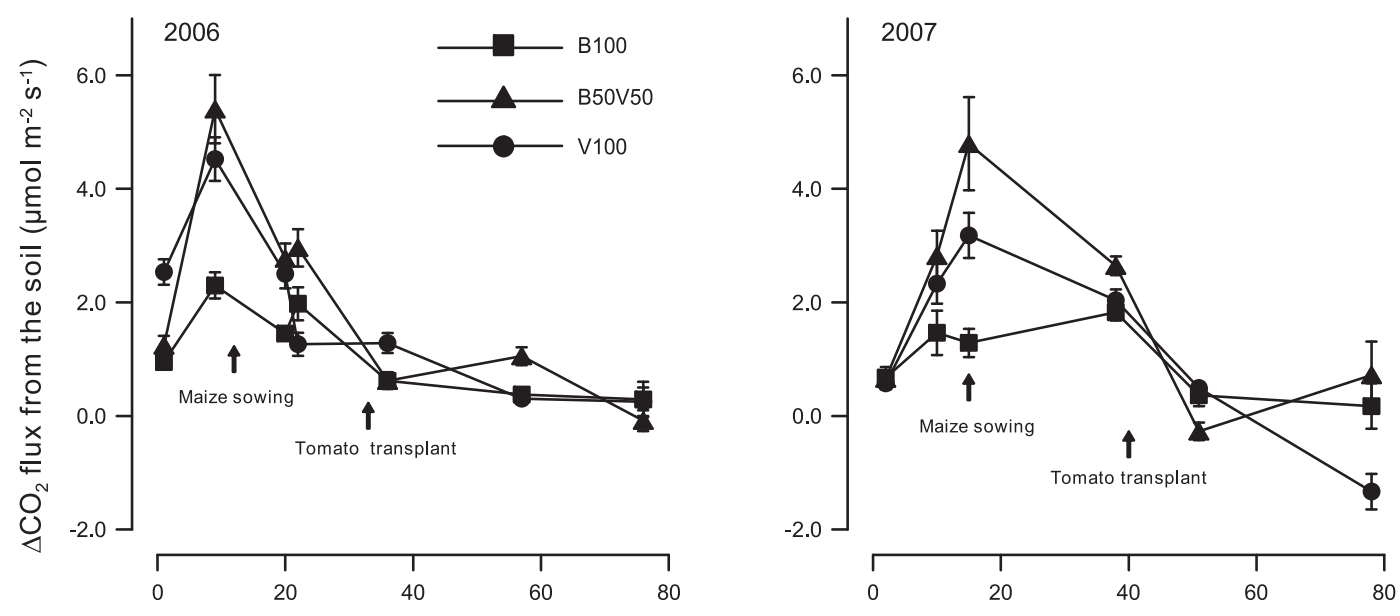

DAI

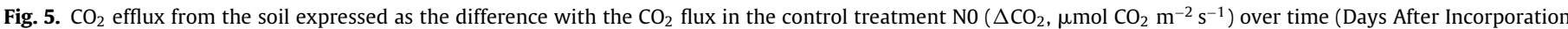

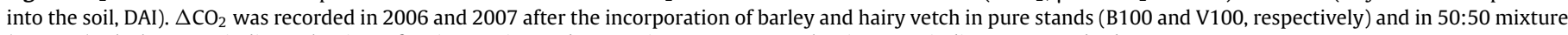
(B50V50). Black arrows indicate the time of maize sowing and processing tomato transplanting. Bars indicate \pm 1 standard error. 

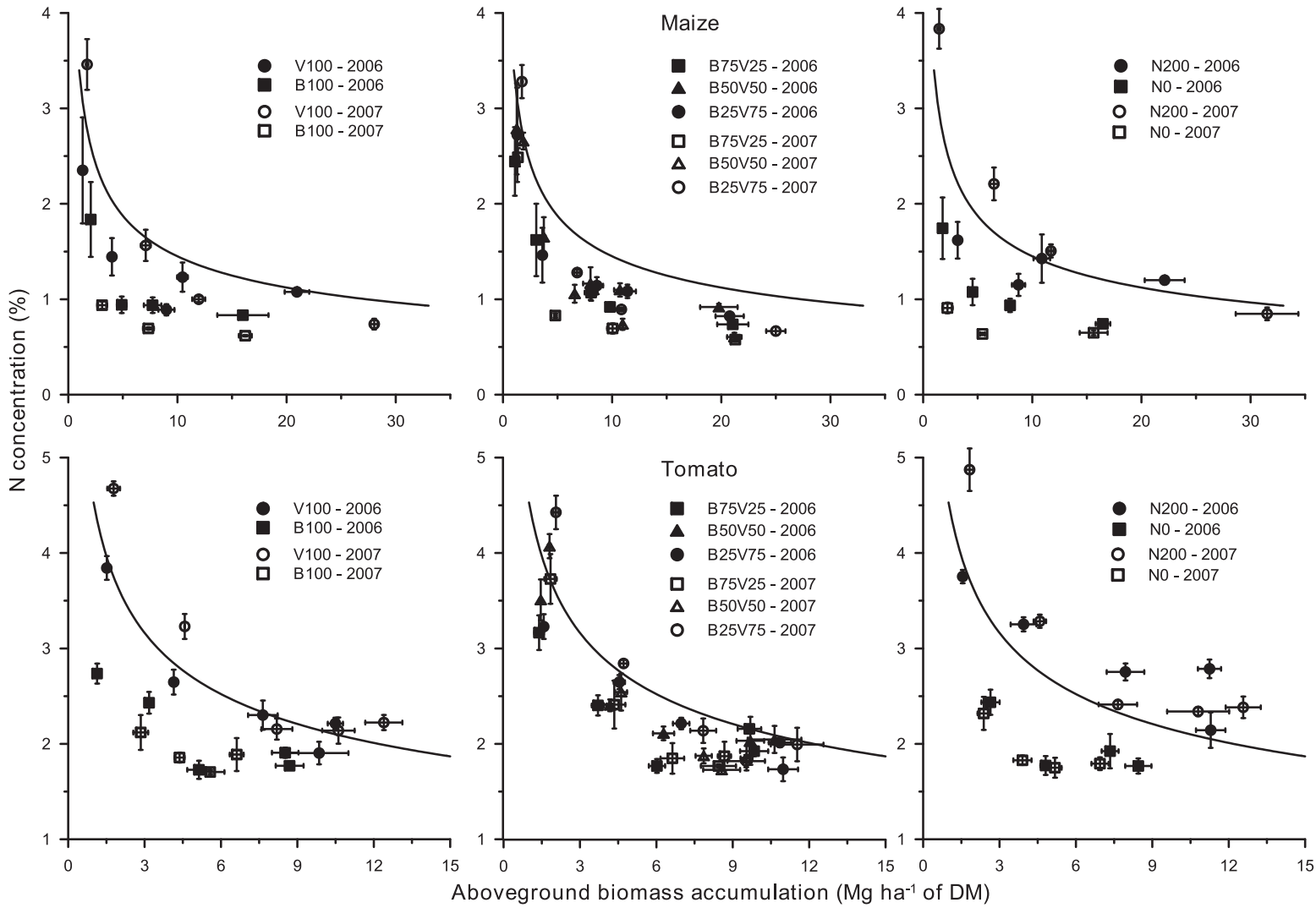

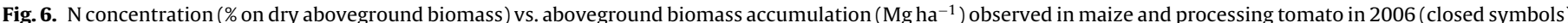

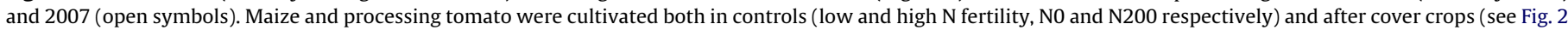

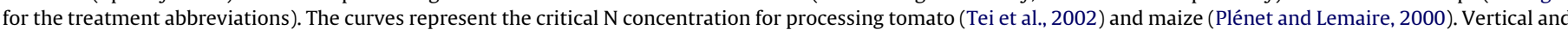
horizontal bars indicate \pm 1 standard error.

differences between the two cash crops were much more evident in 2007 as compared to 2006.

The mean values of $N_{\text {eff }}$ calculated across both years for maize and tomato were compared to the predicted values obtained from the model proposed by Thorup-Kristensen (1994b) for the N mineralization from plant material incorporated into the soil (Eq. (2)). The model predicted the observed values quite well, even if a general underestimation of the observations was found, especially with processing tomato (Fig. 8).
Aboveground biomass production, commercial yield and $\mathrm{N}$ uptake of maize and processing tomato were always significantly influenced by the experimental treatments (preceding cover crops and controls, Table 2) and only aboveground biomass production showed a significant 'treatment by year' interaction, explained by a very high aboveground biomass production with both cash crops (particularly maize) in 2007, when preceded by mineral fertilisation or cover crops with high vetch proportion (V100 and B25V75).

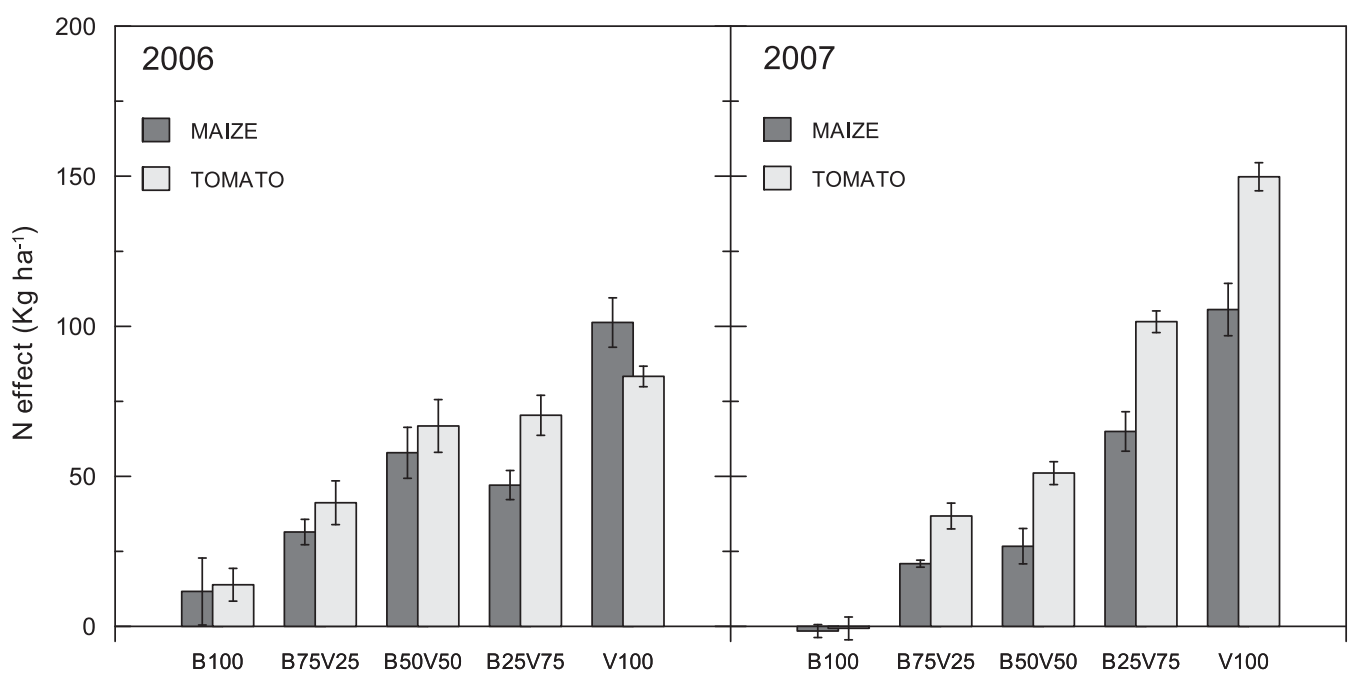

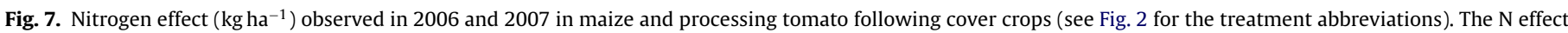
is calculated as the difference in main crop $\mathrm{N}$ uptake after the cover crop treatments and the N0 control treatment (Eq. (1)). Bars indicate \pm 1 standard error. 
Maize

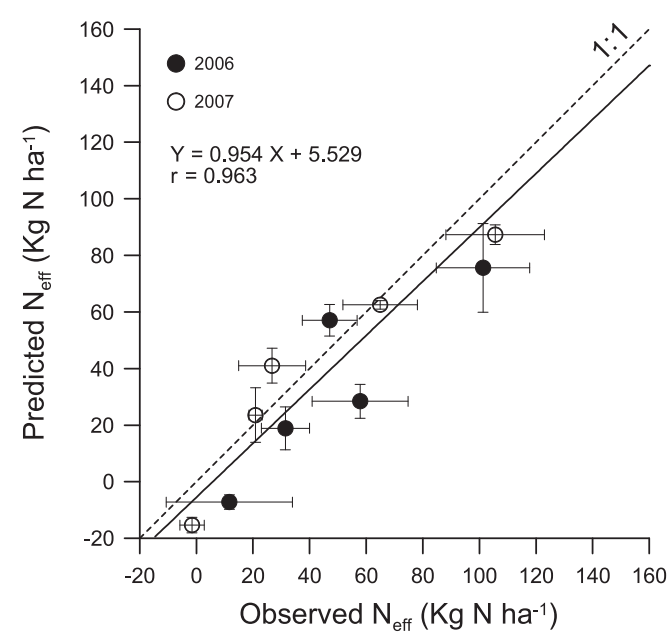

Processing tomato

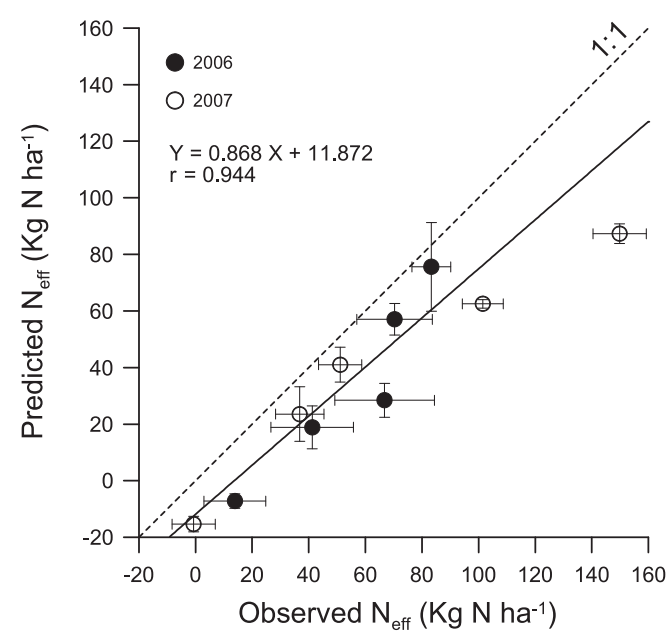

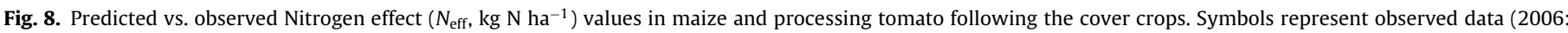

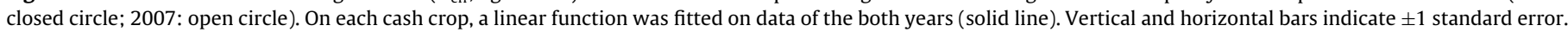

Apart from this interaction, effects were similar in both years: pure barley caused the lowest aboveground biomass production, yield and $\mathrm{N}$ uptake in both species and years (never significantly different from N0).

Considering pure vetch, this cover crop appeared generally more effective on the yield of maize rather than on processing tomato, but, nevertheless, in both species, aboveground biomass and commercial yield in V100 were not significantly different from N200. Otherwise, $\mathrm{N}$ uptake after pure vetch was always lower than in N200, particularly in tomato (Table 2).

Considering the mixtures, effects were more complex. In 2006, both cash crops gave similar aboveground biomass and commercial yields after the three mixtures (B75V25, B50V50 and B25V75), while $\mathrm{N}$ uptake was lower in B75V25. Otherwise, in 2007 aboveground biomass production, commercial yield and nitrogen uptake of both cash crops increased as the vetch sowing proportion increased (Table 2).

\section{Discussion}

\subsection{Cover crops $N$ accumulation}

The reduction in barley growth observed in 2005-2006 with respect to 2006-2007 (Figs. 1 and 2, Table 1) can be ascribed to the very high frequency of intense rainfall events since early November 2005 , which had a strong effect on base $\mathrm{N}$ fertility in soil. This is confirmed by the fact that the growth of vetch was not very much affected by the year.

Aboveground biomass accumulation in mixtures was higher with respect to pure barley, particularly in 2006 (49\% vs 26\% on average). Barley is generally the strongest competitor and thanks to its lower base temperature requirement for growth and faster growth rate, it should be more productive as winter cover crop than hairy vetch (Tosti et al., 2010). However, when its production is low, as in 2005-2006 (Fig. 1), the proportion of leguminous species in the mixture becomes the determining factor for aboveground biomass accumulation of mixtures (Fig. 2 and Table 1). This confirms the high complementarity between species (Hauggaard-Nielsen and Jensen, 2005), which ensures a more stable aboveground biomass accumulation across years.

The presence of vetch in the mixtures led to a remarkable increase in the final $\mathrm{N}$ accumulation. This legume, even at $25 \%$ of its full sowing proportion (i.e. B75V25), brought to increases of
$148 \%$ and $134 \%$ compared to B100 in 2006 and 2007, respectively (Fig. 2). Furthermore, the improvement of $\mathrm{N}$ accumulation was corroborated by a significant decrease in $\mathrm{C} / \mathrm{N}$ ratio. Such a decrease was observed not only on the whole incorporated aboveground biomass (vetch + barley), but also on the barley component taken separately (Figs. 3 and 4), due to the niche separation principle (Haynes, 1980; Jensen, 1996). Consequently, with the incorporation of the mixtures, the soil received a high amount of biomass, with higher quality and more prone to the mineralisation of $C$ and $\mathrm{N}$ as compared with pure barley (Fig. 5).

\subsection{Cover crop $N$ supply and $N_{\text {eff }}$ on the succeeding crop}

It is generally known that when fresh plant material is incorporated into the soil, the initial mineralisation is very fast compared to other organic materials (Kuzyakov et al., 2000; Prescott, 2005; Kuzyakov, 2010). Indeed, $\mathrm{CO}_{2}$ flux from the soil suggests that the most intensive mineralization period occurred within two weeks after ploughing (Fig. 5). Therefore, the initial $\mathrm{N}$ availability for the subsequent crops (especially for maize) was substantially related to the amount of $\mathrm{N}$ released (or immobilised) during this early stage (Fig. 5), when a sort of $\mathrm{N}$ reservoir is built. Our results support the idea that the build up of this initial reservoir was strictly related to the quality (mainly to $\mathrm{C} / \mathrm{N}$ ) of the aboveground biomass incorporated into the soil (Thorup-Kristensen, 1994b; Reddy et al., 2008) and thus it was dependent on the type of cover crop mixtures.

Before discussing the results about $N_{\text {eff }}$, it is necessary to point out that in this experiment the effect of "pre-emptive" competition (Thorup-Kristensen, 1993) has been eliminated by growing and removing pure barley in control plots without incorporation. Therefore, the measured values of $N_{\text {eff }}$ are essentially dependent on $\mathrm{N}$ mineralization. It should also be considered that, if the effect of pre-emptive competition had not been eliminated, the measured $N_{\text {eff }}$ values would have been lower and, in the case of B100, more clearly negative. $N_{\text {eff }}$ observed in maize and processing tomato after B100 was negative in 2007, confirming that the high amount of barley aboveground biomass with high $\mathrm{C} / \mathrm{N}$ ratio led to stronger immobilization than mineralization and thereby to net $\mathrm{N}$ immobilization (Geisseler et al., 2010). On the contrary, in 2006 a small net $\mathrm{N}$ mineralization was observed in B100 (Fig. 7).

$N_{\text {eff }}$ for both cash crops increased while the proportion of vetch in total aboveground biomass increased (Fig. 7) and such an effect is clearly related to the above-mentioned decrease in $\mathrm{C} / \mathrm{N}$ ratio. 
Table 2

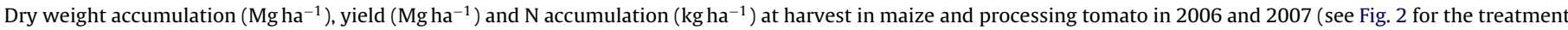
abbreviations). Standard errors (in brackets) and results of the analysis of variance are also reported.

\begin{tabular}{|c|c|c|c|c|c|c|c|c|c|c|c|c|c|}
\hline \multirow{3}{*}{2006} & \multirow[b]{3}{*}{ B100 } & \multicolumn{6}{|c|}{ Maize } & \multicolumn{6}{|c|}{ Processing tomato } \\
\hline & & \multicolumn{2}{|c|}{$\begin{array}{l}\text { Aboveground biomass } \\
\left(\mathrm{Mg} \mathrm{ha}^{-1} \text { of } \mathrm{DM}\right)\end{array}$} & \multicolumn{2}{|c|}{$\begin{array}{l}\text { Grain yield } \\
\left(\mathrm{Mg} \mathrm{ha}^{-1} \text { of DM) }\right.\end{array}$} & \multicolumn{2}{|c|}{$\mathrm{N}$ uptake $\left(\mathrm{kg} \mathrm{ha}^{-1}\right)$} & \multicolumn{2}{|c|}{$\begin{array}{l}\text { Aboveground biomass } \\
\left(\mathrm{Mg} \mathrm{ha}^{-1} \text { of } \mathrm{DM}\right)\end{array}$} & \multicolumn{2}{|c|}{$\begin{array}{l}\text { Fruit yield } \\
\left(\mathrm{Mg} \mathrm{ha}^{-1} \text { of DM) }\right.\end{array}$} & \multicolumn{2}{|c|}{$\mathrm{N}$ uptake $\left(\mathrm{kg} \mathrm{ha}^{-1}\right)$} \\
\hline & & 16.0 & $(2.35)$ & 8.0 & $(1.36)$ & 131.8 & $(22.31)$ & 8.5 & $(0.52)$ & 5.2 & $(0.38)$ & 162.5 & $(10.94)$ \\
\hline & B75V25 & 21.1 & (1.43) & 10.3 & $(0.95)$ & 151.7 & $(8.48)$ & 9.8 & $(0.55)$ & 5.9 & $(0.42)$ & 189.8 & (14.57) \\
\hline & B50V50 & 19.8 & $(1.72)$ & 9.3 & $(1.16)$ & 178.1 & (16.96) & 10.6 & $(1.05)$ & 5.9 & $(0.36)$ & 215.4 & $(17.61)$ \\
\hline & B25V75 & 20.8 & (1.29) & 9.9 & $(0.29)$ & 167.3 & $(9.68)$ & 10.9 & $(0.44)$ & 6.5 & $(0.29)$ & 219.0 & (13.35) \\
\hline & V100 & 20.9 & $(1.12)$ & 11.0 & $(0.63)$ & 221.5 & (16.47) & 10.5 & $(0.3)$ & 6.1 & $(0.18)$ & 231.9 & $(6.83)$ \\
\hline & N200 & 22.1 & $(1.83)$ & 12.2 & $(0.71)$ & 259.8 & $(22.07)$ & 11.2 & $(0.46)$ & 6.2 & $(0.19)$ & 313.3 & $(16.79)$ \\
\hline & NO & 16.5 & $(0.67)$ & 8.1 & $(0.39)$ & 120.2 & $(7.83)$ & 8.5 & $(0.52)$ & 4.9 & $(0.40)$ & 148.6 & $(7.09)$ \\
\hline & Mean & 19.6 & & 9.8 & & 175.8 & & 10.0 & & 5.8 & & 211.5 & \\
\hline \multirow[t]{11}{*}{2007} & B100 & 16.2 & $(0.59)$ & 7.2 & $(0.37)$ & 100.2 & $(4.30)$ & 6.6 & $(0.27)$ & 3.4 & $(0.19)$ & 124.1 & $(7.66)$ \\
\hline & B75V25 & 21.3 & $(0.32)$ & 8.5 & $(0.09)$ & 122.7 & $(2.30)$ & 8.7 & $(0.26)$ & 4.5 & $(0.18)$ & 161.6 & $(8.54)$ \\
\hline & B50V50 & 21.2 & $(0.66)$ & 9.2 & $(0.41)$ & 128.5 & (11.84) & 9.5 & $(0.23)$ & 5.2 & $(0.06)$ & 175.8 & $(7.64)$ \\
\hline & B25V75 & 25.0 & $(0.88)$ & 10.4 & $(0.20)$ & 166.7 & (13.18) & 11.5 & (1.03) & 6.2 & $(0.71)$ & 226.3 & (7.23) \\
\hline & V100 & 28.0 & $(0.33)$ & 11.9 & $(0.26)$ & 207.3 & $(17.44)$ & 12.4 & $(0.73)$ & 5.8 & $(0.54)$ & 274.6 & $(9.40)$ \\
\hline & N200 & 31.5 & (3.59) & 12.4 & $(0.56)$ & 231.2 & (14.09) & 12.6 & $(0.69)$ & 5.8 & $(0.15)$ & 301.1 & (29.99) \\
\hline & NO & 15.6 & $(1.28)$ & 7.2 & $(0.84)$ & 101.8 & (10.65) & 6.9 & $(0.34)$ & 3.3 & $(0.29)$ & 124.8 & $(9.83)$ \\
\hline & Mean & 22.7 & & 9.5 & & 151.2 & & 9.8 & & 4.9 & & 198.3 & \\
\hline & Treatment $(\mathrm{T})$ & $* * *$ & & $* * *$ & & $* * *$ & & $* * *$ & & $* * *$ & & $* * *$ & \\
\hline & $\operatorname{Year}(\mathrm{Y})$ & $* *$ & & ns & & $* *$ & & ns & & $* * *$ & & ns & \\
\hline & $\mathrm{T} \times \mathrm{Y}$ & $*$ & & ns & & ns & & $*$ & & ns & & ns & \\
\hline
\end{tabular}

***: Significantly different at $P<0.001$

**: Significantly different at $P<0.01$

*: Significantly different at $P<0.05$

ns: not significant

Indeed, the main mineralisation effect of the cover crop could be reasonably well predicted, based on its quality, i.e. on $\mathrm{C}$ and $\mathrm{N}$ content in its aboveground biomass (Fig. 8). In order to get an insight of what the effect would be when changing the incorporation date, predictions were made also by using the observed aboveground biomass quality at two earlier dates, with respect to the actual incorporation dates (Table 3 ). These predictions showed that $N_{\text {eff }}$ in V100 and all 'barley + vetch' mixtures should decrease when anticipating aboveground biomass incorporation, while the behaviour in B100 should be opposite. This seems to suggest that the optimal incorporation date depends on the type of the cover crop. Moreover, using 'barley + vetch' mixtures might allow for longer growth during the spring without hindering $N_{\text {eff }}$ (Table 3 ). From our results, we can argue that maize would have probably been more influenced by this delay than processing tomato. Finally, the N supply for both the cash crops was clearly modulated by the different barley/vetch proportions of the cover crops, that also influenced the $\mathrm{C} / \mathrm{N}$ and consequently the $N_{\text {eff }}$ (Fig. 8 and Table 3).

\section{3. $N$ status and yield of maize and processing tomato}

Comparing the $\mathrm{N}$ status of the cash crops to the critical $\mathrm{N}$ dilution curves, confirmed the better response of processing tomato to the mixtures (especially to B25V75) as compared to maize. Maize, in fact, represents a very high $\mathrm{N}$-demanding crop, so its optimal $\mathrm{N}$ status was only reached when it was fertilised with synthetic
$\mathrm{N}$ (N200). Thereby, the $N_{\text {eff }}$ of the different cover crops (especially those with high barley proportions) brought tomato much closer to the critical $\mathrm{N}$ value than they did with maize. Pure vetch did meet the $\mathrm{N}$ requirement of maize only in 2006, while it perfectly satisfied the $\mathrm{N}$ demand of processing tomato in both years (Fig. 6). Maize sowing usually precedes processing tomato transplanting of approximately 20 days; therefore less time is left for $\mathrm{N}$ mineralization before crop establishment. Furthermore, toxic and/or allelopathic compounds released from the decomposing biomass have not been taken into account in this study, but they could have also provoked some kind of negative effect on maize growth, particularly during the early phase (Hill et al., 2007).

As observed, in the considered pedoclimatic conditions the $\mathrm{N}$ immobilization was higher than the mineralization from the barley aboveground biomass leading to a small net $\mathrm{N}$ release in 2006 , while in 2007 the $\mathrm{N}$ accumulated in the pure barley tissues was not available for the cash crop $\left(N_{\text {eff }} \approx 0\right)$. The timing of the release process was mainly influenced by $\mathrm{C} / \mathrm{N}$, rather than by the total $\mathrm{N}$ content of the cover crops aboveground biomass. Even if the non fertilised control supplied an extremely low amount of $\mathrm{N}$ to the cash crops, the effect of pure barley on the $\mathrm{N}$ status of both tomato and maize was even worse. The quality of cover crop aboveground biomass showed a clear effect on the $\mathrm{N}$ availability for the subsequent crop, but, differently from maize, the $N_{\text {eff }}$ values observed in tomato were constantly higher than the predicted ones (Fig. 8). This finding suggests that the basis of the relationship between

Table 3

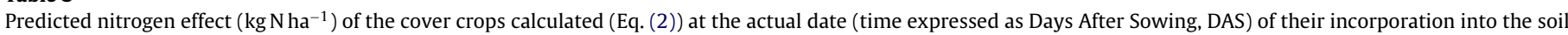

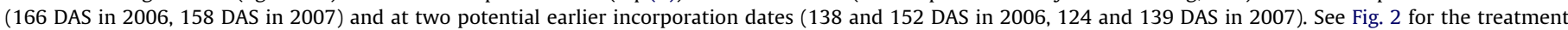
abbreviations. Standard errors are reported in brackets.

\begin{tabular}{|c|c|c|c|c|c|c|c|}
\hline & \multicolumn{4}{|l|}{ DAS 2006} & \multicolumn{3}{|l|}{ DAS 2007} \\
\hline & 138 & 152 & 166 & & 124 & 139 & 158 \\
\hline B100 & $-2.48(1.368)$ & $-4.49(0.485)$ & -7.22 & $(1.828)$ & $4.96(0.641)$ & $-1.30(0.785)$ & $-15.34(1.937)$ \\
\hline B75V25 & $6.89(1.578)$ & $4.39(0.812)$ & 18.86 & $(5.372)$ & $15.83(0.830)$ & $12.74(2.445)$ & $23.56(6.824)$ \\
\hline B50V50 & $10.97(1.204)$ & $15.30(4.198)$ & 28.44 & $(4.228)$ & $21.58(2.011)$ & $26.27(2.845)$ & 41.01 (4.355) \\
\hline B25V75 & $19.94(0.838)$ & 24.14 (1.737) & 57.05 & (3.952) & $26.01(1.631)$ & 51.97 (3.806) & 62.53 (1.059) \\
\hline V100 & $26.03(2.114)$ & 30.04 (3.419) & 75.59 & (11.089) & 39.77 (3.755) & $72.62(2.758)$ & $87.30(2.444)$ \\
\hline
\end{tabular}


cover crop C/N and $N_{\text {eff }}$ was well-founded, even though the characteristics of the subsequent crop may play a role and should also be taken into account.

The effect of the cover crops on yield was quite similar for both cash crops. Amongst all the cover crop treatments, V100 allowed the best yield in maize, while the effect of B25V75 on the yield of processing tomato was better than that observed in pure vetch (Table 3). The total $\mathrm{N}$ supplied by B25V75, and the $\mathrm{C} / \mathrm{N}$ of this mixture allowed a very good development of the photosynthetic structures of the crop, and, on the other hand, an optimal homogeneity and better synchrony in the ripening of the processing tomato fruits (i.e. less unmarketable fruits). These results led to a better yield as compared to V100 or even to N200 (Table 2).

\section{Conclusions}

- Using mixtures proved to be a very effective strategy for the management of winter cover crops, because barley and vetch complement each other very well, as the grass is capable of high growth rates during the cold season, while vetch becomes very important in spring, when $\mathrm{N}$ becomes the limiting factor. Changing the proportion of species within the mixture can be a key factor to adjust the extent and timing of $\mathrm{N}$ mineralisation to the nutritional requirements of the following crop.

- Likewise, changing the above proportion can be very important to ensure a good quality of the incorporated biomass (with particular reference to $\mathrm{C} / \mathrm{N}$ ratio), which is fundamental for a good initial growth and $\mathrm{N}$ status of the subsequent cash crop.

- Aboveground biomass quality is central to predict its $N_{\text {eff }}$ on the subsequent crop. Therefore, the implementation of simple models for such a prediction appears to be a useful approach, even though our findings suggest that it may be important to consider also the characteristics of the following cash crop.

- The adoption of mixtures in the optimization of the "cover crop strategy" should be considered in order to improve the $\mathrm{N}$ use efficiency. In particular, the potential applications of cover crop mixtures for the mitigation of environmental risks caused by $\mathrm{N}$ leaching need to be better investigated, especially in the Mediterranean environment.

\section{Acknowledgments}

Authors would like to thank Mr. Rossano Cortona for his skilled technical assistance and all the technicians at the Experimental Station of Papiano for their invaluable help with the field work. Finally, we thank Dr. Andrea Onofri for his critical revision of the manuscript. Research funded by the FISR SIMBIO-VEG (2005-08).

\section{References}

Allen, R.G., Pereira, L.S., Raes, D., Smith, M., 1998. Crop evapotranspiration. Guidelines for computing crop water requirements. FAO Irrigation and Drainage Paper 56. FAO, Rome, Italy.

Bardgett, R.D., Wardle, D.A., 2010. Aboveground-Belowground Linkages: Biotic Interactions, Ecosystem Processes, and Global Change. Oxford University Press.

Benincasa, P., Tosti, G., Tei, F., Guiducci, M., 2010. Actual N availability from winter catch crops used for green manuring in maize cultivation. Journal of Sustainable Agriculture 34, 705-723.

Campiglia, E., Caporali, F., Radicetti, E., Mancinelli, R., 2010. Hairy vetch (Vicia villosa Roth) cover crop residue management for improving weed control and yield in no-tillage tomato (Lycopersicon esculentum Mill.) production. European Journal of Agronomy 33, 94-102.

Caporali, F., Campiglia, E., Mancinelli, R., Paolini, R., 2004. Maize performances as influenced by winter cover crop green manuring. Italian Journal of Agronomy 8, $37-45$.

Cazzato, E., Annese, V., Corleto, A., 2003. $\mathrm{N}_{2}$ fixation of annual fodder legumes in Mediterranean environment. 1. Estimation of $\mathrm{N}_{2}$ fixation by isotope dilution. Rivista di Agronomia 37, 57-61.

Connolly, J., 1986. On difficulties with replacement-series methodology in mixture experiments. Journal of Applied Ecology 23, 125-137.
Constantin, J., Beaudoin, N., Laurent, F., Cohan, J.P., Duyme, F., Mary, B., 2011. Cumulative effects of catch crops on nitrogen uptake, leaching and net mineralization. Plant Soil 341, 137-154.

Crews, T.E., Peoples, M.B., 2005. Can the synchrony of nitrogen supply and crop demand be improved in legume and fertilizer-based agroecosystems? A review. Nutrient Cycling in Agroecosystems 72, 101-120.

de Wit, C.T., van den Bergh, J.P., 1965. Competition between herbage plants. Netherlands Journal of Agricultural Science 13, 212-221.

Fan, F., Zhang, F., Song, Y., Sun, J., Bao, X., Guo, T., Li, L., 2006. Nitrogen fixation of faba bean (Vicia faba L.) interacting with a non-legume in two contrasting intercropping systems. Plant Soil 283, 275-286.

Gabriel, J.L., Quemada, M., 2011. Replacing bare fallow with cover crops in a maize cropping system: yield, $\mathrm{N}$ uptake and fertiliser fate. European Journal of Agronomy 34, 133-143.

Geisseler, D., Horwath, W.R., Joergensen, R.G., Ludwig, B., 2010. Pathways of nitrogen utilization by soil microorganisms - a review. Soil Biology \& Biochemistry 42, 2058-2067.

Hauggaard-Nielsen, H., Jensen, E.S., 2005. Facilitative root interactions in intercrops. Plant Soil 274, 237-250.

Haynes, R.J., 1980. Competitive aspects of the grass-legume association. Advances in Agronomy 33, 227-261.

Hill, E.C., Ngouajio, M., Nair, M.G., 2007. Allelopathic potential of Hairy Vetch (Vicia Villosa) and Cowpea (Vigna Unguiculata) methanol and ethyl acetate extracts on weeds and vegetables. Weed Technology 21, 437-444.

Isaac, R.A., Johnson, W.C., 1976. Determination of total nitrogen in plant tissue, using a block digestor. Journal of AOAC 59, 98-100.

Jensen, E.S., 1996. Grain yield, symbiotic $\mathrm{N}_{2}$ fixation and interspecific competition for inorganic N in pea-barley intercrops. Plant Soil 182, 25-38.

Kramberger, B., Gselman, A., Janzekovic, M., Kaligaric, M., Bracko, B., 2009. Effects of cover crops on soil mineral nitrogen and on the yield and nitrogen content of maize. European Journal of Agronomy 31, 103-109.

Kuzyakov, Y., 2006. Sources of $\mathrm{CO}_{2}$ efflux from soil and review of partitioning methods. Soil Biology \& Biochemistry 38, 425-448.

Kuzyakov, Y., 2010. Priming effects interactions between living and dead organic matter. Soil Biology \& Biochemistry 42, 1363-1371.

Kuzyakov, Y., Friedel, J.K., Stahr, K., 2000. Review of mechanisms and quantification of priming effects. Soil Biology \& Biochemistry 32, 1485-1498.

Lampkin, N., 1990. Organic Farming. Farming Press, Ipswich (UK).

Ledgard, S.F., Giller, K.E., 1995. Atmospheric N2 fixation as an alternative N source. In: Bacon, P.E. (Ed.), Nitrogen Fertilization in the Environment. Marcel Dekker Inc., New York, pp. 443-486.

Macdonald, A.J., Poulton, P.R., Howe, M.T., Goulding, K.W.T., Powlson, D.S., 2005. The use of cover crops in cereal-based cropping systems to control nitrate leaching in SE England. Plant and Soil 273, 355-373.

Myers, R.J.K., Palm, C.A., Cuevas, E., Gunatilleke, I.U.N., Brossard, M., 1994. The synchronisation of nutrient mineralisation and plant nutrient demand. In: Woomer, P.L., Swift, M.J. (Eds.), The Biological Management of Tropical soil Fertility. John Wiley \& Sons, Chichester (UK), pp. 81-116.

Ofori, F., Stern, W.R., 1987. Cereal-legume intercropping systems. Advances in Agronomy 41, 41-90.

Peoples, M.B., Herridge, D.F., Ladha, J.K., 1995. Biological nitrogen fixation: an efficient source of nitrogen for sustainable agricultural production? Plant and Soil $174,3-28$.

Plénet, D., Lemaire, G., 2000. Relationship between dynamics of nitrogen uptake and dry matter accumulation in maize crops. Determination of critical $N$ concentration. Plant and Soil 216, 65-82.

Prescott, C.E., 2005. Decomposition and mineralization of nutrients from litter and humus. In: BassiriRad, H. (Ed.), Nutrient Acquisition by Plants. Springer-Verlag, Berlin/Heidelberg, pp. 15-41.

Quemada, M., 2004. Predicting crop residue decomposition using moisture adjusted time scales. Nutrient Cycling in Agroecosystems 70, 283-291.

R Development Core Team. 2009. R: A language and environment for statistical computing. R Foundation for Statistical Computing, Vienna, Austria. ISBN 3900051-07-0, URL http://www.R-project.org.

Ranells, N.N., Wagger, M.G., 1997. Grass-legume bicultures as winter annual cover crops. Agronomy Journal 89, 659-665.

Reddy, K.S., Mohanty, M., Rao, D.L.N., Singh, M., Dalal, R.C., Rao, A.S., Pandey, M. Menzies, N., 2008. Nitrogen mineralization in a vertisol from organic manures, green manures and crop residues in relation to their quality. Agrochimica 52, 377-388.

Salmeron, M., Isla, R., Cavero, J., 2011. Effect of winter cover crop species and planting methods on maize yield and $\mathrm{N}$ availability under irrigated Mediterranean conditions. Field Crops Research 123, 89-99.

Stockdale, E.A., Shepherd, M.A., Fortune, S., Cuttle, S.P., 2002. Soil fertility in organic farming systems - fundamentally different? Soil Use Management 18, 301-308.

Teasdale, J.R., Abdul-Baki, A.A., Park, Y.B., 2008. Sweet corn production and efficiency of nitrogen use in high cover crop residue. Agronomy for Sustainable Development 28, 559-565.

Tei, F., Benincasa, P., Guiducci, M., 2002. Critical nitrogen concentration in processing tomato. European Journal of Agronomy 18, 45-55.

Thorup-Kristensen, K., 1993. The effect of nitrogen catch crops on the nitrogen nutrition of a succeeding crop. Effects through mineralization and pre-emptive competition. Acta Agriculturæ Scandinavica 43, 74-81.

Thorup-Kristensen, K., 1994a. The effect of nitrogen catch crop species on the nitrogen nutrition of succeeding crops. Fertility Research 37, 227-234. 
Thorup-Kristensen, K., 1994b. An easy pot incubation method for measuring nitrogen mineralization from easily decomposable organic material under well defined conditions. Fertility Research 38, 239-247.

Thorup-Kristensen, K., Nielsen, N.E., 1998. Modelling and measuring the effect of nitrogen catch crops on the nitrogen supply for succeeding crops. Plant and Soil 203, 79-89.

Thorup-Kristensen, K., Magid, J., Jensen, L.S., 2003. Catch crops and green manures as biological tools in nitrogen management in temperate zones. Advances in Agronomy 79, 227-302.
Tosti, G., Benincasa, P., Guiducci, M., 2010. Competition and facilitation in hairy vetch-barley intercrops. Italian Journal of Agronomy 3, 239-247.

van Kessel, C., Hartley, C., 2000. Agricultural management of grain legumes: has it led to an increase in nitrogen fixation? Field Crops Research 65, 165-181.

Vos, J., Van der Putten, P.E.L., 1997. Field observations on nitrogen catch crops. I. Potential and actual growth and nitrogen accumulation in relation to sowing date and crop species. Plant and Soil 195, 299-309.

Vos, J., Van der Putten, P.E.L., 2001. Field observations on nitrogen catch crops. III. Transfer of nitrogen to the succeeding main crop. Plant and Soil 236, 263-273. 